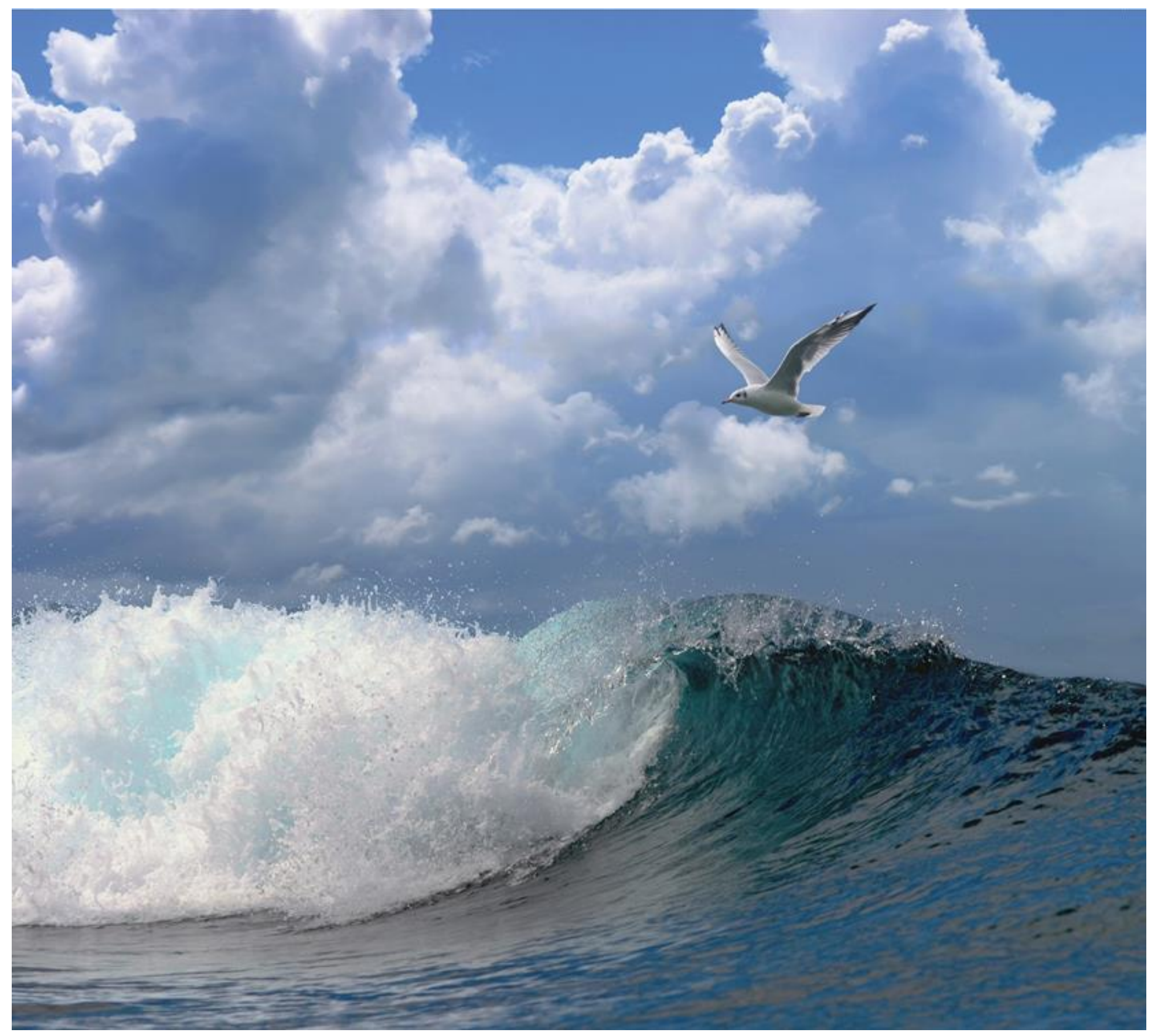

Feasibility study of the development of population models for the northern fulmar (Fulmarus glacialis) and the Atlantic puffin (Fratercula arctica) 


\section{Feasibility study of the development of population models for the northern fulmar (Fulmarus glacialis) and the Atlantic puffin (Fratercula arctica)}

Author(s): Vincent Hin, Floor Soudijn

Wageningen Marine Research 
Client: $\quad$ Rijkswaterstaat Water, Verkeer en Leefomgeving Postbus 2232

$3500 \mathrm{GE}$, Utrecht

This report can be downloaded for free from https://doi.org/10.18174/546670 Wageningen Marine Research provides no printed copies of reports

Wageningen Marine Research is ISO 9001:2015 certified.

\section{(C) Wageningen Marine Research}

Wageningen Marine Research, an institute Wageningen Marine Research accepts no liability for consequential damage, nor within the legal entity Stichting Wageningenfor damage resulting from applications of the results of work or other data Research (a foundation under Dutch private obtained from Wageningen Marine Research. Client indemnifies Wageningen law) represented by Dr.ir. J.T. Dijkman, Managing director Marine Research from claims of third parties in connection with this application. All rights reserved. No part of this publication may be reproduced and / or published, photocopied or used in any other way without the written permission of the publisher or author.

KvK nr. 09098104,

WMR BTW nr. NL 8113.83.696.B16.

Code BIC/SWIFT address: RABONL2U

IBAN code: NL 73 RABO 0373599285

A_4_3_2 V31 (2021) 


\section{Contents}

Memo haalbaarheid populatiemodellen voor zes zeevogelsoorten t.b.v. Kader Ecologie en Cumulatie 4.0

Summary

1 Introduction

$2 \quad$ Methods

2.1 Population models

2.2 Data requirements

2.3 Data sources

3

\section{Results}

3.1 Northern fulmar - Fulmarus glacialis

3.2 Atlantic puffin - Fratercula arctica

4 Conclusions and recommendations

4.1 Northern fulmar - Fulmarus glacialis

4.2 Atlantic puffin - Fratercula arctica

References

Justification

Annex 1 Demographic parameters of selected seabird species 


\section{Summary}

This memo assesses whether sufficient information is available to develop stage-structured matrix population models for two species of seabirds, the northern fulmar (Fulmarus glacialis) and the Atlantic puffin (Fratercula arctica). Development of such models requires age-specific estimates of survival and reproduction rates. For both species, there is sufficient information on adult survival rate and colony productivity (reproduction rate), but the survival of immature birds is less well studied. There is little evidence for density-dependent effects on survival and reproduction. We conclude that density-independent population models for these species can be developed and that model robustness with respect to immature survival should be addressed during model analysis. We advise to go ahead with the development of the models for these species. 


\section{Introduction}

The KEC (in Dutch: "Kader Ecologie en Cumulatie") assesses the cumulative impact of offshore wind farms (OWFs) in the North Sea on populations of protected seabird species. The last version of KEC (KEC 3.0) stems from 2018 and predicts the additional mortality from habitat displacement and collision risks resulting from national and international planned OWFs up to 2030 (van der Wal et al., 2018). The North Sea Programme 2022 - 2027 of the Dutch Government designates search areas for new OWFs that are to be constructed up until the year 2040. The potential effects on populations of protected seabird species need to be recalculated based on these additional, planned OWFs. This requires an update of KEC 3.0 to KEC 4.0 .

The impact of OWFs on seabirds can occur either through habitat loss resulting from OWF avoidance or from additional mortality due to wind turbine collisions, depending on whether a particular species is attracted to, avoiding, or ignoring OWFs. Within KEC 3.0, the species that might suffer habitat loss were addressed separately from those that might experience additional mortality from increased collision risk. Effects of habitat loss were considered for five seabird species, namely red-throated diver (Gavia stellata), northern gannet (Morus bassanus), sandwich tern (Thalasseus sandvicensis), razorbill (Alca torda) and common guillemot (Uria aalge). For these species, population models were developed and used to calculate the predicted mortality effects of habitat loss on future population trajectories as part of a separate project (van Kooten et al., 2019) that was part of the 'offshore wind energy ecological programme' (Wozep). In the KEC 4.0 assessment, two additional seabird species (Table 1) will be included: northern fulmar (Fulmarus glacialis) and Atlantic puffin (Fratercula arctica), which were selected because of their wide ranging wintering distribution and their potential vulnerability for the effect of displacement by OWFs (Dierschke et al., 2016; Furness et al., 2013). Population models for these two species still need to be developed. The current memo describes the type of data that are required for the formulation of such population models and gives an overview of the data available for these two species. Finally, an assessment is made on whether the available data are of sufficient quality to warrant their use in a population model.

Table 1 KEC 4.0 additional species for population modelling

\begin{tabular}{lll} 
Species name & Scientific name & Dutch name \\
Northern fulmar & Fulmarus glacialis & Noordse stormvogel \\
\hline Atlantic puffin & Fratercula arctica & Papegaaiduiker \\
\hline
\end{tabular}




\subsection{Population models}

The KEC 4.0 assessment will use the same type of population models as used by Van Kooten et al. (2019). These are stage-structured matrix population models that track the number of individuals within different life stages. Individuals within a particular life stage have the same survival probability and reproductive output. At a particular point in time, the population is described by the population state: the number of individuals within each life stage. The population state can be projected forward in time by multiplying it with a matrix containing the stage-specific annual survival probabilities and reproductive output. This leads to an estimate of the population growth rate: the yearly relative change in population density. A Monte Carlo method can be used to determine the uncertainty of the population growth rate that stems from uncertainty in the estimates of survival and reproduction. This method samples many parameter values from the distributions of survival and reproduction and calculates the population growth rate for each sample.

Increased mortality due to displacement from OWFs will only be experienced by a subset of the population and may differ per season. To identify what fraction of the population suffers from increased mortality, we need information on the number of birds displaced and on the total size of the population to which these birds belong. To estimate the size of the population of origin of the birds displaced from OWFs, information about population abundance, distribution and movement patterns in and outside the breeding season is required.

Van Kooten et al. (2019) developed density-independent population models, which means that the population growth rate is independent of the population size. Although density-dependent processes are important drivers of the dynamics of any population (Brook and Bradshaw, 2006; Sibly, 2005), including seabird populations, most population models used for impact assessment do not include density dependence, because the form and strength of density dependence are often poorly understood and highly context-dependent (Horswill et al., 2017; Horswill and Robinson, 2015). In addition, most of the known density-dependent mechanisms for seabird populations operate on the scale of the colony (Horswill and Robinson, 2015) and it is unknown how important these densitydependent mechanisms are on a meta-population level (Breton et al., 2006) or how they relate to other changes in rates of survival and reproduction in seabirds, for example from large-scale environmental changes (Fayet et al., 2021; Grosbois and Thompson, 2005; Miller et al., 2019; Thompson and Ollason, 2001). A final argument for the use of density-independent population models is based on the precautionary principle. Without density dependence, there are no compensatory effects on mortality or reproduction. Therefore observed changes in population growth rates can be regarded as a worst-case scenario.

\subsection{Data requirements}

To parameterize a stage-structured matrix model, requires estimates of several demographic parameters related to survival and reproduction. In (sea)birds, age is an important determinant of survival and reproduction, therefore the subdivision in life stages is primarily based on individual age. Consequently, age-specific estimates of annual survival probability are a necessary ingredient to parameterize a stage-structured matrix model. Generally, seabirds have high adult survival, which varies little throughout life. For most seabird species, estimates of adult survival are available from mark-recapture or ring-recovery studies, without knowing the true age of the marked individuals. These adult survival rates fit well within the chosen modelling framework, by adopting an adult life stage that spans all reproductively active ages. Survival is generally lower and more variable in the first year of life, and increases with age during the first, immature years of life (Doherty et al., 2004). Overall, there are fewer estimates available on survival of immature animals, or the available 
estimates are based on low sample sizes or have poor representation (e.g. only reflect a single colony or time period). In summary, we ideally require three types of data to parameterize survival:

1. Estimate of adult survival.

2. Estimate of survival during first year of life

3. Estimate of survival during immature years

To parameterize the reproduction component of the projection matrix, we require at least three types of data:

1. An estimate of fertility, or the mean number of female offspring produced by a single female during each breeding season. Productivity estimates, which give the colony mean number of fledged individuals per breeding pair or nest, if available, can be used as fertility estimate in case the model contains a single adult life stage.

2. An estimate of the age of recruitment, or the age at first breeding.

3. An estimate of the fraction of adults that skip breeding ('floaters') or the 'incidence of missed breeding'. In some species, adult females do not breed every year and this should be accounted for in the fertility matrix.

For all demographic parameters, we collected mean values and estimates of their variation. Estimates of parameter variation are required to assess robustness of the population projections and calculate uncertainty ranges around the model results. Different measures of variation that could be used for this purpose are the standard deviation, the range (minimum and maximum values) and $95 \%$ confidence intervals of the parameter estimates.

The available evidence for density-dependent effects on rates of survival and / or reproduction is shortly reviewed.

Lastly, we shortly discuss the abundance and distribution of both species and their (seasonal) movement patterns in and around the North Sea.

\subsection{Data sources}

We searched for demographic parameters of the species listed in Table 1 using Google Scholar (https://scholar.google.com), the online Wageningen University and Research Library Search (https://www.wur.nl/en/library.htm) and ResearchGate (https://www.researchgate.net/). These searches mainly targeted peer-reviewed articles in scientific journals. We used the keywords 'demograph*', 'survival', 'reproduction', 'population model' in combination with the scientific or English names of the species in Table 1. Obtained papers were scanned for relevant references and any reported demographic parameters were traced back to their original source. If full texts could not be retrieved, data were obtained from abstracts if available. In addition, we searched the online resource hub of the British Joint Nature Conservation Committee (JNCC) at https://hub.jncc.gov.uk/search for information on seabird colonies within the UK and Ireland. Lastly, we consulted the relevant species accounts of the online Birds of the World research database from The Cornell Lab of Ornithology. The performed searches were by no means complete or exhaustive, but merely served to obtain a minimum set of demographic parameter estimates that allowed parameterization of the stagestructured population models with an acceptable level of confidence. 


\subsection{Northern fulmar - Fulmarus glacialis}

\subsubsection{Abundance and distribution}

Across the Atlantic, the northern fulmar has shown dramatic spread and increase in numbers over the past 250 years and now breeds in hundreds of colonies around the coasts of Iceland, Faeroes and British Isles (Mallory et al., 2020), including dozens of colonies along the British North Sea coast (Mitchell et al., 2004). This increase has come to a halt several decades ago and the Seabird 2000 census estimated around 1.1 million breeding birds in Britain and Ireland, with highest densities in Northern Scotland. This number has changed little since the 1985-1988 census (Mitchell et al., 2004), but most recent monitoring shows a decline in the number of breeding pairs in most UK colonies (JNCC, 2020). For other countries around the North Sea, Mitchell et al. (2004) report 1,155 breeding pairs in France, 53 breeding pairs in Germany and in between 6,000 and 7,000 breeding pairs in Norway, excluding Svalbard and Jan Mayen.

\subsubsection{Movement and dispersal}

Outside the breeding season, the northern fulmar can disperse widely across the North Atlantic (Quinn, 2014), although some breeding birds in boreal regions remain near their colonies year round (Mallory et al., 2020). Using geolocation loggers, Grissot et al. (2019) show that 135 birds that breed at the Eynhallow colony, Orkney Islands, were moulting across a broad geographical range from the mid-Atlantic to the Barents Sea (their Fig. 4), with one group of predominantly males moulting in the northern part of the North Sea. Quinn (2014) studied autumn and winter distribution of Fulmars breeding at Eynhallow and revealed two broad areas of high density, one along the NE Atlantic shelf (East coast of UK, Northern North Sea, Norwegian shelf water and Barents Sea) and one in the Western Atlantic. Although there was considerable intra-individual variability in wintering areas, for the majority of birds (54/67) the Northern North Sea was the area in which they spent the majority of their winter (Quinn, 2014). The Southern North Sea was used very little as wintering area by birds breeding at the Eynhallow colony (Quinn, 2014). Also during egg incubation, birds from Eynhallow can disperse far from their colony, with some birds using the mid-Atlantic, although most females (68\%) foraged over the Norwegian Shelf and most males (60\%) remained within the greater North Sea area (Edwards et al., 2016). We did not find tracking studies of birds breeding at colonies south of Eynhallow and we therefore have no detailed information on the use of the Southern North Sea. Results from ship-based and aerial surveys indicate that Fulmars use the Southern North Sea to a lesser extent than the Northern North Sea (Leopold, 2017; Waggitt et al., 2020).

\subsubsection{Demography}

A selection of demographic parameters is listed in Annex 1. Demography of the northern fulmar has been extensively studied on Eynhallow Island (Orkney Islands, Scotland), where birds have been ringed and monitored since 1950 (Dunnet, 1991). This yielded estimates on adult survival (Buckland, 1982; Cordes et al., 2015; Grosbois and Thompson, 2005), breeding / fledging success (Lewis et al., 2009; Quinn, 2014), recruitment into breeding population (fraction fledged chicks that recruited into

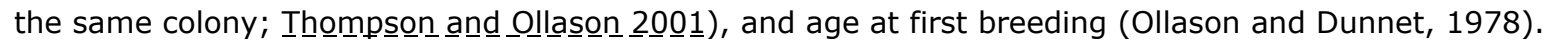
The number of breeding adults on Eynhallow reached a maximum of 200 pairs in 1984 and has decreased since then to around 100 breeding pairs in more recent years (2004 - 2012; Quinn, 2014). Consequently, demographic parameters from this site are only representative of a very small subset of the total breeding population, which is estimated at 500,000 pairs for Scotland (Cordes et al., 2015; Horswill and Robinson, 2015; Mitchell et al., 2004). A recent analysis revealed a declining trend of adult survival rates of birds from Eynhallow between 1974 and 2009 (Cordes et al., 2015). 


\subsubsection{Survival estimates}

Apart from Eynhallow Is, there are estimates on adult survival from a colony on Little Saltee, SouthEastern Ireland, where Fulmars have been ringed and recaptured regularly since 1974 (Cordes et al., 2015). Adult survival rates of Fulmars breeding at Little Saltee are higher, but show a similar decreasing trend through time as adult survival rates of birds from Eynhallow (Cordes et al., 2015). However, direct estimates of immature survival are sparse. Dunnet et al. (1979) report an estimate of 0.88 for annual survival obtained from birds aged 1 to 9 years (reported_by_Kerbiriou__et_al_._2012), but the accuracy and associated variability of this estimate is uncertain. For the related southern fulmar (Fulmarus glacialoides), survival of fledged birds until recruitment as breeders at a mean age of 11 years was on average $0.26(+/-0.15)$ (Jenouvrier et al., 2003), which equals an annual survival probability of 0.884 (Horswill and Robinson, 2015). Although this estimate corresponds remarkably well with that of Dunnet et al. (1979), it is higher than immature survival rates of most other seabirds (Horswill and Robinson, 2015).

\subsubsection{Reproduction estimates}

An indication of the spatial variability in productivity can be obtained from Mavor et al. (2008), who report mean (S.E.) breeding success (chicks fledged per Apparently Occupied Site) of 30 colonies throughout Britain and Ireland across the years 1986 - 2005. Productivity estimates up until 2018 for several colonies in Great Britain can be obtained from https://jncc.gov.uk/our-work/smp-report-19862018/. Site-specific estimates of number of breeding pairs and breeding success are available from Isle of May (Newell et al., 2016, 2013), Fair Isle (Shaw et al., 2002) and Skomer Island (Stubbings et al., 2018).

Estimates of recruitment rates of fledged individuals into the breeding population are given by Dunnet et al. (1979), who report that only $3 \%$ of ringed fledglings during 28 years of study returned to breed on Eynhallow, even though most fledglings were ringed. Similarly, Thompson and Ollason (2001) showed that the recruitment fraction of 23 cohorts of fledged chicks (birth years $1958-1980$ ) varied between $0 \%$ and $8 \%$, with a mean of $4.2 \%$. These low local recruitment rates can either be explained by low immature survival or high natal dispersal. Which one of these two processes is most dominant matters considerably for the (meta)population dynamics of Fulmars.

Northern fulmars show high mate and site-fidelity (Ollason and Dunnet, 1978), but may skip breeding in certain years, especially when environmental / prey conditions are poor (Jenouvrier et al., 2003; Lewis et al., 2009; Thompson and Ollason, 2001). The incidence of missed breeding in this species is poorly resolved (Horswill and Robinson, 2015), but several sources might provide an estimate of this parameter. Thompson and Ollason (2001) report the fraction of breeding adults present at the Eynhallow colony during 36 breeding seasons (mean fraction across years equalled 0.7 ), but do not explicitly state that presence at colony implies breeding. Kerbiriou et al. (2012) studied metapopulation dynamics of northern fulmars breeding in Brittany, France and estimated the mean proportion of breeders among adults at 0.684 . Unpublished information is reported for a population at Cape Vera, Nunavut, Canada, where 68\% of 106 pairs bred in both studied years (2004-2005), while $32 \%$ bred once in those years (Mallory et al., 2020).

\subsubsection{Density dependence}

Several aspects of demographic performance of the northern fulmar have been related to environmental conditions. Both Thompson and Ollason (2001) and Lewis et al. (2009) showed that large-scale ocean climate variability (North Atlantic Oscillation) has a lagged effect on breeding performance (recruitment rate, hatching success and fledgling success). Furthermore, colony size did not influence these reproductive parameters and breeding success was positively related to colony size (Lewis et al., 2009). Adult survival rates of birds from Eynhallow were negatively related to the winter North Atlantic Oscillation, which decreased over the study period (Grosbois and Thompson, 2005). A similar decrease in survival rates was observed for birds at the Little Saltee colony, Ireland, which suggests that changes in survival rates are indicative of processes beyond the scale of the local colony (Cordes et al., 2015). 


\subsection{Atlantic puffin - Fratercula arctica}

\subsubsection{Abundance and distribution}

The Atlantic puffin breeds on offshore islands both on West and East Atlantic, including Iceland, Faeroes, Svalbard and Jan Mayen. The Seabird 2000 census estimated total number of breeding Atlantic Puffins on Britain and Ireland at 600,751 (AOB: Apparently Occupied Burrows), with strongholds in Shetland, the Western Isles of Scotland, Northumberland and Orkney (Mitchell et al., 2004), but numbers have declined since then (Harris and Wanless, 2011). The southernmost puffin colonies in the North Sea are at Bempton Cliffs and Flamborough Head, where numbers have declined since the 1980s (Harris and Wanless, 2011; Mitchell et al., 2004). There are no breeding colonies along the British Channel coast and approximately 300-350 pairs breed on the Channel Islands (Harris and Wanless, 2011). For other countries around the North Sea, Harris and Wanless (2011) report 150 breeding pairs in Brittany, France in 2009 and around 1,7 million breeding pairs in Norway, excluding Svalbard and Jan Mayen, but the vast majority of these birds breed above the Arctic circle.

\subsubsection{Movement and dispersal}

Outside the breeding season, Atlantic puffins are strictly pelagic and rarely seen close to shore (Harris et al., 2005; Lowther et al., 2020a). Tracking of Puffins with geolocator loggers (GLS) revealed that birds breeding at Isle of May predominately stayed within the north-western part of the North Sea in late winter (Harris et al., 2013), whereas birds from Skomer Island, Wales, do not enter the North Sea and move west or south (Fayet et al., 2017). Norwegian seabird tracking data of 514 individuals from 18 different colonies indicate a low probability of presence in the Southern North Sea (below 53N) year round (https://seatrack.seapop.no/map/) and Harris et al. (2013) state that Puffins are "extremely uncommon in the Southern North Sea". During the breeding season, GPS equipped birds breeding at Isle of May mainly foraged within 30-60 km of the colony, although there were indications that instrumented birds were hampered in their foraging behaviour and sample sizes were low (Harris et al., 2012). Unpublished results from the Farne Islands indicated that the majority of foraging during the breeding season occurs within $20 \mathrm{~km}$ of the colony, but foraging distance from the colony obviously depends on local feeding conditions (Harris et al., 2012). In general, Puffins are present in low densities on the Dutch Continental Shelf in winter months (November-April) only (Fijn et al., 2019).

\subsubsection{Demography}

A selection of demographic parameters is listed in Annex 1.

\subsubsection{Survival estimates}

Adult survival rates of Atlantic Puffins breeding at various colonies in the North-East Atlantic are given by Harris et al. (2005). Overall, adult survival rates are high without any big differences between colonies. A recent survival analysis of an ongoing monitoring study at Isle of May by Anker-Nilssen et al. (2017) shows that annual survival and resighting rates varied significantly among years between 1991 and 2017. Harris et al. (2013) present part of the same data, but up to 2010 and going back to 1984. Survival rates, pre-breeding movement and natal dispersal probabilities of immature animals were estimated by Breton et al. (2006) from data of 2050 chicks from four colonies in the Gulf of Maine (USA and Canada). Estimates of immature survival for East-Atlantic birds are reported by Harris (1983) and Ashcroft (1979), but these estimates might be unreliable as they are based on return rates and potentially biased by ring-loss (Horswill and Robinson, 2015). Sandvik et al. (2008) showed that immature birds (0-5 years) from Hornøya, Northern Norway, had annual survival rates comparable with annual adult survival rates during the same period.

\subsubsection{Reproduction estimates}

Within the UK and Ireland, colony-specific estimates of yearly breeding success are reported for Isle of May (Harris et al., 2013; Newell et al., 2016, 2013), Fair Island (Shaw et al., 2002), Farne Island, Skomer and St. Kilda (Ashcroft, 1979; Mavor et al., 2008; Stubbings et al., 2018). Productivity estimates up until 2018 for several colonies in Great Britain can be obtained from https://jncc.gov.uk/our-work/smp-report-1986-2018/. Fayet et al. (2017) report breeding 
performance estimates of 12 colonies around the North-Atlantic (Canada, USA, Iceland, UK, Ireland \& Norway). Adult breeding dispersal is considered low (Ashcroft, 1979; Breton et al., 2006; Harris, 1983; Harris and Wanless, 2011; Lowther et al., 2020b), while natal dispersal is thought to be higher, although most movement is between nearby colonies (Harris, 1983; Lowther et al., 2020b). An exception is the study of Sandvik (2008), who report that dispersal of immatures was extremely rare or absent at the Hornøya colony in Northern Norway.

For birds breeding at Isle of May, the usual age at first breeding is between four and six years, although some birds were observed to breed at the age of three years (Harris, 1983). Similar results were found for birds breeding at Skomer Island, Wales (Ashcroft, 1979). More recently, Anker-Nilssen et al. (2017) refer to Harris and Wanless (2011) and report that puffins rarely breed before five years old. A very low estimate of the incidence of missed breeding is reported by Ashcroft (1979). This estimate was based on a short time series for a single colony and has poor spatio-temporal representation (Horswill and Robinson, 2015). Lowther et al. (2020b) state that age at first breeding is variable, but that puffins breed annually thereafter. If any, the incidence of missed breeding is unlikely to be substantial.

\subsubsection{Density dependence}

There is limited evidence for density-dependent effects on rates of survival and reproduction of Puffins. Decline in availability of forage fish can reduce breeding success and survival rates of auks (Anker-Nilssen and Rostad, 1993; Harris and Bailey, 1992), but this is unlikely to be an effect of bird density. Breton et al. (2006) detected a negative, density-dependent response in survival probabilities of adult and immature Puffins, using colony size as a measure of bird density. However, like many other seabirds, mortality in alcids mainly occurs during winter, when birds disperse widely (Harris and Wanless, 2011). Given this, it seems unlikely that colony size is an important factor in the regulation of puffin population abundance. 


\section{$4 \quad$ Conclusions and recommendations}

\subsection{Northern fulmar - Fulmarus glacialis}

The northern fulmar has a particularly slow life history, with delayed onset of reproduction and high adult survival. Adult breeding birds have high site fidelity, facilitating reliable estimation of adult survival rates. However, there is little information on immature birds and the fate of fledglings is little studied. In addition, incidence of missed breeding is poorly resolved (Horswill and Robinson, 2015). There is no clear indication of density dependence in the population dynamics of this species, which seem to be driven more by large-scale environmental changes. At present, development of a densitydependent population model is not recommended. Altogether, there is sufficient information to develop a population model for the northern fulmar, but the robustness of the obtained population growth rate to changes in immature survival, natal dispersal and incidence of missed breeding will have to be accounted for. This can readily be done by performing sensitivity / elasticity analysis or assessing a range of different values for each of these demographic parameters. Previous work on long lived seabirds has shown that population growth rates are less sensitive to uncertainty in immature survival compared to adult survival (Caswell, 2001; Doherty et al., 2004). We advise to proceed with the development of the model for this species.

\subsection{Atlantic puffin - Fratercula arctica}

The effect of habitat loss due to OWF is likely to occur only in winter, as puffins are rare in the Southern North Sea in the breeding season. Of the five different colonies studied by Harris et al. (2005), only birds breeding at Isle of May seemed to be wintering in the North Sea, but other colonies on the North Sea coast of Britain (Farne Island, Coquet Island, Bempton) not studied by Harris et al. (2005) might contribute to the birds wintering in the Southern North Sea. Demographic performance of birds from these colonies will therefore be most relevant for the current project. Long-term data on adult survival and mean colony productivity are available from the Isle of May, but estimates of immature survival and natal dispersal are less well resolved and likely more variable between years. There is a lack of clear evidence about the role of density dependence in the population dynamics of this species and development of a density-dependent population model is therefore not recommended. Altogether, there is sufficient information to develop a population model for the Atlantic puffin, but model analysis will have to account for parameter uncertainty relating to immature survival and natal dispersal in similar ways as suggested for the northern fulmar. We advise to go ahead with the development of the model for this species. 


\section{Quality Assurance}

Wageningen Marine Research utilises an ISO 9001:2015 certified quality management system. This certificate is valid until 15 December 2021. The organisation has been certified since 27 February 2001. The certification was issued by DNV GL. 


\section{References}

Anker-Nilssen, T., Harris, M.P., Kleven, O., Langset, M., 2017. Status, origin, and population level impacts of Atlantic Puffins killed in a mass mortality event in southwest Norway early 2016. SEABIRD 30, 1-14.

Anker-Nilssen, T., Rostad, O.W., 1993. Census and Monitoring of Puffins Fratercula arctica on Rost, N Norway, 1979-1988. Ornis Scand. 24, 1. https://doi.org/10.2307/3676402

Ashcroft, R.E., 1979. Survival Rates and Breeding Biology of Puffins on Skomer Island, Wales. Ornis Scand. 10, 100. https://doi.org/10.2307/3676349

Breton, A.R., Diamond, A.W., Kress, S.W., 2006. Encounter, survival, and movement probabilities from an Atlantic Puffin (Fratercula arctica) metapopulation. Ecol. Monogr. 76, 133-149. https://doi.org/10.1890/05-0704

Brook, B.W., Bradshaw, C.J.A., 2006. Strength of evidence for density dependence in abundance time series of 1198 species. Ecology 87, 1445-1451. https://doi.org/10.1890/00129658(2006)87[1445:SOEFDD]2.0.CO;2

Buckland, S.T., 1982. A Mark-Recapture Survival Analysis. J. Anim. Ecol. 51, 833. https://doi.org/10.2307/4008

Caswell, H., 2001. Matrix Population Models: Construction Analysis and Interpretation, 2nd ed. Sinauer Associates, Sunderland.

Cordes, L.S., Hedworth, H.E., Cabot, D., Cassidy, M., Thompson, P.M., 2015. Parallel declines in survival of adult Northern Fulmars Fulmarus glacialis at colonies in Scotland and Ireland. Ibis 157, 631-636.

Dierschke, V., Furness, R.W., Garthe, S., 2016. Seabirds and offshore wind farms in European waters: Avoidance and attraction. Biol. Conserv. 202, 59-68. https://doi.org/10.1016/j.biocon.2016.08.016

Doherty, P.F., Schreiber, E.A., Nichols, J.D., Hines, J.E., Link, W.A., Schenk, G.A., Schreiber, R.W., 2004. Testing life history predictions in a long-lived seabird: a population matrix approach with improved parameter estimation 13.

Dunnet, G.M., 1991. Population studies of the Fulmar on Eynhallow, Orkney Islands. Ibis 133, 24-27. https://doi.org/10.1111/j.1474-919X.1991.tb07665.x

Dunnet, G.M., Ollason, J.C., Anderson, A., 1979. A 28-year study of breeding fulmars Fulmarus glacialis in Orkney. Ibis 121, 293-300. https://doi.org/10.1111/j.1474-919X.1979.tb06846.x

Edwards, E.W.J., Quinn, L.R., Thompson, P.M., 2016. State-space modelling of geolocation data reveals sex differences in the use of management areas by breeding northern fulmars. J. Appl. Ecol. 53, 1880-1889. https://doi.org/10.1111/1365-2664.12751

Fayet, A.L., Clucas, G.V., Anker-Nilssen, T., Syposz, M., Hansen, E.S., 2021. Local prey shortages drive foraging costs and breeding success in a declining seabird, the Atlantic puffin. J. Anim. Ecol. 00, 1-13. https://doi.org/10.1111/1365-2656.13442

Fayet, A.L., Freeman, R., Anker-Nilssen, T., Diamond, A., Erikstad, K.E., Fifield, D., Fitzsimmons, M.G., Hansen, E.S., Harris, M.P., Jessopp, M., Kouwenberg, A.-L., Kress, S., Mowat, S., Perrins, C.M., Petersen, A., Petersen, I.K., Reiertsen, T.K., Robertson, G.J., Shannon, P., Sigurðsson, I.A., Shoji, A., Wanless, S., Guilford, T., 2017. Ocean-wide Drivers of Migration Strategies and Their Influence on Population Breeding Performance in a Declining Seabird. Curr. Biol. 27, 3871-3878.e3. https://doi.org/10.1016/j.cub.2017.11.009

Fijn, R.C., van Bemmelen, R.S.A., Arts, F.A., de Jong, J.W., Beuker, D., Bravo Rebolledo, E.L., Engels, B.W.R., Hoekstein, M., Jonkvorst, R.-J., Lilipaly, S., Sluijter, M., van Straalen, K.D., Wolf, P.A., 2019. Verspreiding, abundantie en trends van zeevogels en zeezoogdieren op het Nederlands Continentaal Plat in 2019-2020 (No. Bureau Waardenburg Rapportnr. 20-324). Bureau Waardenburg \& Deltamilieu Projecten, Culemborg.

Furness, R.W., Wade, H.M., Masden, E.A., 2013. Assessing vulnerability of marine bird populations to offshore wind farms. J. Environ. Manage. 119, 56-66. https://doi.org/10.1016/j.jenvman.2013.01.025

Grissot, A., Graham, I.M., Quinn, L., Bråthen, V.S., Thompson, P.M., 2019. Breeding status influences timing but not duration of moult in the Northern Fulmar Fulmarus glacialis. Ibis 162, 446-459. https://doi.org/10.1111/ibi.12714

Grosbois, V., Thompson, P.M., 2005. North Atlantic climate variation influences survival in adult fulmars. Oikos 109, 273-290. https://doi.org/10.1111/j.0030-1299.2005.13774.x

Harris, M.P., 1983. Biology and survival of the immature Puffin Fratercula arctica. Ibis 125, 56-71. https://doi.org/10.1111/j.1474-919X.1983.tb03083.x 
Harris, M.P., Anker-Nilssen, T., McCleery, R.H., Erikstad, K.E., Shaw, D.N., Grosbois, V., 2005. Effect of wintering area and climate on the survival of adult Atlantic puffins Fratercula arctica in the eastern Atlantic. Mar Ecol Prog Ser 297, 283-296.

Harris, M.P., Bailey, R.S., 1992. Mortality rates of puffin Fratercula arctica and guillemot Uria aalge and fish abundance in the North Sea. Biol. Conserv. 60, 39-46. https://doi.org/10.1016/0006-3207(92)90797-Q

Harris, M.P., Bogdanova, M.I., Daunt, F., Wanless, S., 2012. Using GPS technology to assess feeding areas of Atlantic Puffins Fratercula arctica. Ringing Migr. 27, 43-49. https://doi.org/10.1080/03078698.2012.691247

Harris, M.P., Daunt, F., Bogdanova, M.I., Lahoz-Monfort, J.J., Newell, M.A., Phillips, R.A., Wanless, S., 2013. Inter-year differences in survival of Atlantic puffins Fratercula arctica are not associated with winter distribution. Mar. Biol. 160, 2877-2889. https://doi.org/10.1007/s00227-0132278-5

Harris, M.P., Wanless, S., 2011. The Puffin. T. \& A.D. Poyser, London.

Horswill, C., O'Brien, S.H., Robinson, R.A., 2017. Density dependence and marine bird populations: are wind farm assessments precautionary? J. Appl. Ecol. 54, 1406-1414. https://doi.org/10.1111/1365-2664.12841

Horswill, C., Robinson, R.A., 2015. Review of Seabird Demographic Rates and Density Dependence (No. JNCC Report No. 552). Peterborough.

Jenouvrier, S., Barbraud, C., Weimerskirch, H., 2003. Effects of climate variability on the temporal population dynamics of southern fulmars: Climate variability and fulmar population dynamics. J. Anim. Ecol. 72, 576-587. https://doi.org/10.1046/j.1365-2656.2003.00727.x

JNCC, 2020. SMP Report 1986 - 2018 The Northern Fulmar. Joint Nature Conservation Committee.

Kerbiriou, C., Le Viol, I., Bonnet, X., Robert, A., 2012. Dynamics of a northern fulmar (Fulmarus glacialis) population at the southern limit of its range in Europe. Popul. Ecol. 54, 295-304. https://doi.org/10.1007/s10144-012-0306-9

Leopold, M.F., 2017. Seabirds? What seabirds? An exploratory study into the origin of seabirds visiting the SE North Sea and their survival bottlenecks (No. Wageningen Marine Research report C046/17). Wageningen Marine Research, Den Helder. https://doi.org/10.18174/416194

Lewis, S., Elston, D.A., Daunt, F., Cheney, B., Thompson, P.M., 2009. Effects of extrinsic and intrinsic factors on breeding success in a long lived seabird. Oikos 118, 521-528. https://doi.org/10.1111/j.1600-0706.2008.17308.x

Lowther, P.E., Diamond, A.W., Kress, S.W., Robertson, G.J., Russell, K., Nettleship, D.N., Kirwan, G.M., Christie, D., Sharpe, C., Garcia, E., Boesman, P.F.D., 2020a. Atlantic Puffin (Fratercula arctica), in: Billerman, S.M., Keeney, B.K., Rodewald, P.G., Schulenberg, T.S. (Eds.), Birds of the World. Cornell Lab of Ornithology. https://doi.org/10.2173/bow.atlpuf.01

Lowther, P.E., Diamond, A.W., Kress, S.W., Robertson, G.J., Russell, K., Nettleship, D.N., Kirwan, G.M., Christie, D., Sharpe, C., Garcia, E., Boesman, P.F.D., 2020b. Atlantic Puffin (Fratercula arctica), in: Billerman, S.M., Keeney, B.K., Rodewald, P.G., Schulenberg, T.S. (Eds.), Birds of the World. Cornell Lab of Ornithology. https://doi.org/10.2173/bow.atlpuf.01

Mallory, M.L., Hatch, S.A., Nettleship, D.N., 2020. Northern Fulmar (Fulmarus glacialis), in: Billerman, S.M., Keeney, B.K., Rodewald, P.G., Schulenberg, T.S. (Eds.), Birds of the World. Cornell Lab of Ornithology. https://doi.org/10.2173/bow.norful.01

Mavor, R.A., Heubeck, M., Schmitt, S., Parsons, M., 2008. Seabird numbers and breeding success in Britain and Ireland, 2006 (No. 31), UK Nature Conservation. Joint Nature Conservation Committe, Peterborough.

Miller, J.A.O., Furness, R.W., Trinder, M., Matthiopoulos, J., 2019. The sensitivity of seabird populations to density-dependence, environmental stochasticity and anthropogenic mortality. J. Appl. Ecol. 56, 2118-2130. https://doi.org/10.1111/1365-2664.13448

Mitchell, P.I., Newton, S.F., Ratcliffe, N., Dunn, T.E., 2004. Seabird Populations of Britain and Ireland 14.

Newell, M., Harris, M.P., Gunn, C.M., Burthe, S., Wanless, S., Daunt, F., 2016. Isle of May seabird studies in 2015 (No. JNCC Report No. 475k). Joint Nature Conservation Committe, Peterborough.

Newell, M., Harris, M.P., Skene, A., Wanless, S., Daunt, F., 2013. Isle of May seabird studies in 2010 (No. JNCC Report No. 475f). Joint Nature Conservation Committe, Aberdeen.

Ollason, J.C., Dunnet, G.M., 1978. Age, Experience and Other Factors Affecting the Breeding Success of the Fulmar, Fulmarus glacialis, in Orkney. J. Anim. Ecol. 47, 961. https://doi.org/10.2307/3681

Quinn, L.R., 2014. Intra- and inter-colony differences in non-breeding strategies in the Northern fulmar, Fulmarus glacialis. University of Aberdeen. 
Sandvik, H., Erikstad, K.E., Fauchald, P., Tveraa, T., 2008. High Survival of Immatures in a Long-lived Seabird: Insights from a Long-term Study of the Atlantic Puffin (Fratercula arctica). The Auk $125,723-730$.

Scottish Natural Heritage, 2020. Scottish Biodiversity Indicator - S005 - The numbers and breeding seabirds.

Shaw, D.N., Holt, C.A., Maggs, H.E., de Palacio, D., 2002. Fair Isle Seabird Studies 2000 (No. JNCC Report No. 332). Peterborough.

Sibly, R.M., 2005. On the Regulation of Populations of Mammals, Birds, Fish, and Insects. Science 309, 607-610. https://doi.org/10.1126/science.1110760

Stubbings, E.M., Buche, B.I., Riordan, J.A., Baker, B., Wood, M.J., 2018. Seabird monitoring on Skomer Island in 2018 (No. JNCC Report). Joint Nature Conservation Committe, Peterborough.

Thompson, P.M., Ollason, J.C., 2001. Lagged effects of ocean climate change on fulmar population dynamics. Nature 413, 417-420. https://doi.org/10.1038/35096558

van der Wal, J.T., van Puijenbroek, M.E.B., Leopold, M.F., 2018. Cumulatieve effecten van offshore wind parken: habitatverlies. Update voor vijf zeevogelsoorten, met vooruitblik tot 2030 (No. C059/18). Wageningen Marine Research, Den Helder. https://doi.org/10.18174/458277

van Kooten, T., Soudijn, F., Tulp, I., Chen, C., Benden, D., Leopold, M., 2019. The consequences of seabird habitat loss from offshore wind turbines, version 2 : Displacement and population level effects in 5 selected species (No. C063/19). Wageningen Marine Research, IJmuiden. https://doi.org/10.18174/496173

Waggitt, J.J., Evans, P.G.H., Andrade, J., Banks, A.N., Boisseau, O., Bolton, M., Bradbury, G., Brereton, T., Camphuysen, C.J., Durinck, J., Felce, T., Fijn, R.C., Garcia-Baron, I., Garthe, S., Geelhoed, S.C.V., Gilles, A., Goodall, M., Haelters, J., Hamilton, S., Hartny-Mills, L., Hodgins, N., James, K., Jessopp, M., Kavanagh, A.S., Leopold, M., Lohrengel, K., Louzao, M., Markones, N., Martínez-Cedeira, J., Ó Cadhla, O., Perry, S.L., Pierce, G.J., Ridoux, V., Robinson, K.P., Santos, M.B., Saavedra, C., Skov, H., Stienen, E.W.M., Sveegaard, S., Thompson, P., Vanermen, N., Wall, D., Webb, A., Wilson, J., Wanless, S., Hiddink, J.G., 2020. Distribution maps of cetacean and seabird populations in the North-East Atlantic. J. Appl. Ecol. 57, 253269. https://doi.org/10.1111/1365-2664.13525 


\section{Justification}

Report C046/21

Project Number: 4315100166

The scientific quality of this report has been peer reviewed by a colleague scientist and a member of the Management Team of Wageningen Marine Research
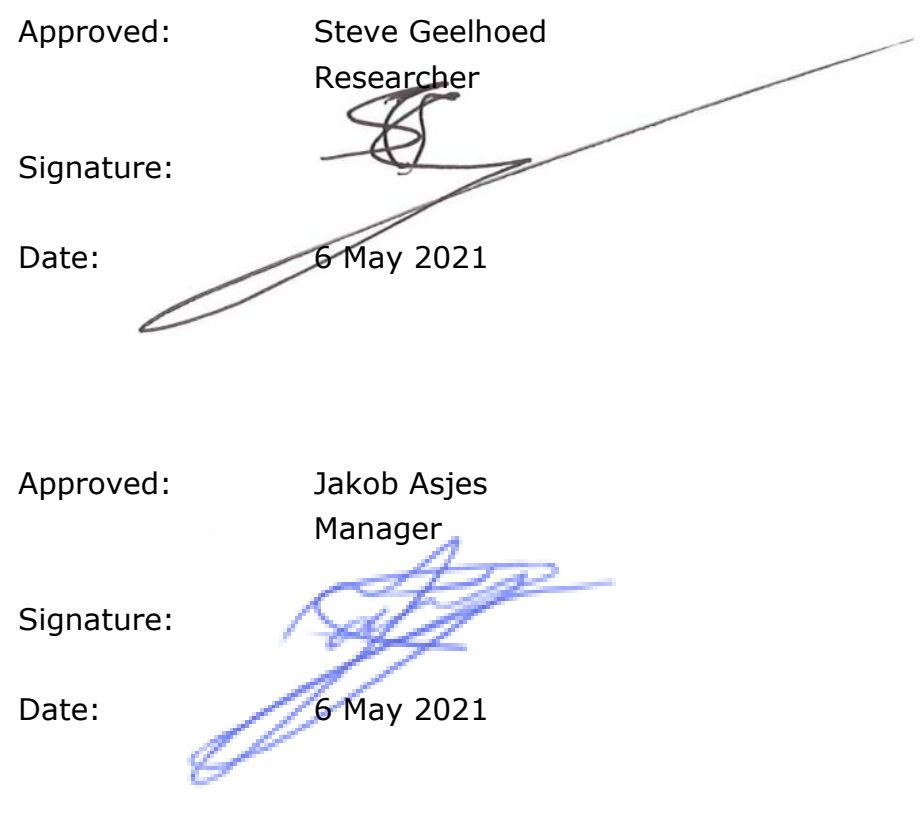


\section{Annex 1 Demographic parameters for northern fulmar and Atlantic puffin}

Table 1 Demographic parameters for northern fulmar - Fulmarus glacialis

\begin{tabular}{|c|c|c|c|c|c|c|c|c|c|}
\hline Location & Country & Parameter & Mean & $\begin{array}{l}\text { Variability } \\
\text { value }\end{array}$ & $\begin{array}{l}\text { Variability } \\
\text { type }\end{array}$ & $\begin{array}{l}\text { N } \\
\text { years }\end{array}$ & $\begin{array}{l}\mathrm{N} \\
\text { ind. }\end{array}$ & Reference & Cited by / note \\
\hline \multicolumn{10}{|l|}{ Survival estimates } \\
\hline Eynhallow, Orkney Islands & Scotland & Adult survival & 0.968 & 0.0042 & SE & 22 & & (Buckland, 1982) & \\
\hline Eynhallow, Orkney Islands & Scotland & Adult survival & & & & & & (Cordes et al., 2015) & \\
\hline Little Saltee & Ireland & Adult survival & & & & & & (Cordes et al., 2015) & \\
\hline Eynhallow, Orkney Islands & Scotland & Adult survival & 0.936 & 0.055 & SD & 34 & & (Grosbois and Thompson, 2005) & (Horswill and Robinson, 2015) \\
\hline Eynhallow, Orkney Islands & Scotland & Immature survival & $0.88-0.93$ & & & & & (Dunnet et al., 1979) & (Kerbiriou et al., 2012) \\
\hline Ile des Petrels, Terre Adelie & Antarctica & Immature survival & 0.26 & 0.15 & SD & 39 & 915 & (Jenouvrier et al., 2003) & \\
\hline \multicolumn{10}{|l|}{ Reproduction estimates } \\
\hline Eynhallow, Orkney Islands & Scotland & Breeding success & 0.411 & 0.021 & SE & 45 & 312 & (Lewis et al., 2009) & (Horswill and Robinson, 2015) \\
\hline Various regions & Scotland & Breeding success & 0.46 & 0.03 & SE & 21 & & (Scottish Natural Heritage, 2020) & \\
\hline Isle of May & Scotland & Breeding success & 0.362 & 0.028 & SE & 19 & 2580 & (Newell et al., 2016, 2013) & Weighted average $1997-2015$ \\
\hline Skomer Island & Wales & Breeding success & 0.39 & 0.023 & SE & 7 & 828 & (Stubbings et al., 2018) & Weighted average $2012-2018$ \\
\hline Fair Isle & Scotland & Breeding success & 0.44 & 0.03 & SE & 11 & & (Shaw et al., 2002) & Average $1990-2000$ \\
\hline Eynhallow, Orkney Islands & Scotland & Probability breeding & 0.70 & 0.113 & SD & 36 & 987 & (Thompson and Ollason, 2001) & \\
\hline Eynhallow, Orkney Islands & Scotland & Age first breeding & 10.3 & 0.6 & SE & & 10 & (Ollason and Dunnet, 1978) & (Horswill and Robinson, 2015) \\
\hline Eynhallow, Orkney Islands & Scotland & Recruitment & 0.042 & 0.0051 & $\mathrm{SE}$ & 23 & 1281 & (Thompson and Ollason, 2001) & Extracted from Figure 3 \\
\hline Ouessant Island, Brittany & France & Proportion breeders & 0.68 & 0.027 & SE & 9 & & (Kerbiriou et al., 2012) & \\
\hline
\end{tabular}


Table 2 Demographic parameters for Atlantic puffin - Fratercula arctica

\begin{tabular}{|c|c|c|c|c|c|c|c|c|c|}
\hline Location & Country & Parameter & Mean & $\begin{array}{l}\text { Variability } \\
\text { value }\end{array}$ & $\begin{array}{l}\text { Variability } \\
\text { type }\end{array}$ & $\begin{array}{l}\text { N } \\
\text { years }\end{array}$ & $\begin{array}{l}\mathrm{N} \\
\text { ind. }\end{array}$ & Reference & Cited by / note \\
\hline \multicolumn{10}{|c|}{ Survival estimates } \\
\hline Isle of May & Scotland & Adult survival & 0.922 & $0.866-0.963$ & $95 \% \mathrm{CI}$ & 23 & & (Harris et al., 2013) & $1984-2006$ \\
\hline Skomer Island & Wales & Adult survival & 0.91 & & & 46 & & (Stubbings et al., 2018) & $1972-2017$ \\
\hline Skomer Island & Wales & Adult survival & 0.930 & 0.050 & SD & 18 & & (Harris et al., 2005) & $1984-2001$ \\
\hline Isle of May & Scotland & Adult survival & 0.935 & 0.050 & SD & 18 & & (Harris et al., 2005) & $1984-2001$ \\
\hline Fair Isle & Scotland & Adult survival & 0.935 & 0.090 & SD & 16 & & (Harris et al., 2005) & $1986-2001$ \\
\hline Rost & Norway & Adult survival & 0.935 & 0.04 & SD & 12 & & (Harris et al., 2005) & $1990-2001$ \\
\hline Hornoya & Norway & Adult survival & 0.935 & 0.025 & SD & 12 & & (Harris et al., 2005) & $1990-2001$ \\
\hline Hornoya & Norway & Adult survival & 0.943 & $0.909-0.965$ & $95 \% \mathrm{CI}$ & & 629 & (Sandvik et al., 2008) & $>1990$ \\
\hline New Brunswick & Canada & Immature survival (age $0-3$ ) & 0.709 & 0.0221 & SE & 24 & 2050 & (Breton et al., 2006) & $1980-2003$ \\
\hline New Brunswick & Canada & Immature survival (age 4) & 0.776 & 0.0188 & SE & 24 & 2050 & (Breton et al., 2006) & $1980-2003$ \\
\hline New Brunswick & Canada & Immature survival (age 5) & 0.805 & 0.017 & SE & 24 & 2050 & (Breton et al., 2006) & $1980-2003$ \\
\hline Hornoya & Norway & Immature survival (age $0-5$ ) & 0.933 & $0.806-0.993$ & $95 \% \mathrm{CI}$ & 2 & 251 & (Sandvik et al., 2008) & 1994-1995 \\
\hline \multicolumn{10}{|c|}{ Reproduction estimates } \\
\hline Isle of May & Scotland & Breeding success & 0.65 & $0.68-0.78$ & $95 \% \mathrm{CI}$ & 22 & & (Harris et al., 2013) & $1984-2005$ \\
\hline Isle of May & Scotland & Breeding success & 0.66 & 0.124 & SD & 19 & & (Newell et al., 2016) & $1997-2015$ \\
\hline Fair Island & Scotland & Breeding success & 0.712 & 0.108 & SD & 11 & & (Shaw et al., 2002) & $1990-2000$ \\
\hline Skomer Island & Wales & Breeding success & 0.62 & & & 1 & & (Stubbings et al., 2018) & 2018 \\
\hline Isle of May & Scotland & Natal dispersal & 0.23 & & & 6 & & (Harris, 1983) & $1972-1979$ \\
\hline Isle of May & Scotland & Age of recruitment & 5 & & & 6 & & (Harris, 1983) & $1972-1979$ \\
\hline Skomer Island & Wales & Age of recruitment & 5 & & & 3 & & (Ashcroft, 1979) & $1973-1975$ \\
\hline Skomer Island & Wales & Incidence of missed breeding & 0.078 & & & 3 & & (Ashcroft, 1979) & $1973-1975$ \\
\hline
\end{tabular}


Wageningen Marine Research

T +31 (0)31748 7000

E: marine-research@wur.nl

www.wur.eu/marine-research

Visitors' address

- Ankerpark 271781 AG Den Helder

- Korringaweg 7, 4401 NT Yerseke

- Haringkade 1, 1976 CP IJmuiden
With knowledge, independent scientific research and advice, Wageningen Marine Research substantially contributes to more sustainable and more careful management, use and protection of natural riches in marine, coastal and freshwater areas.

Wageningen Marine Research is part of Wageningen University \& Research. Wageningen University \& Research is the collaboration between Wageningen University and the Wageningen Research Foundation and its mission is: 'To explore the potential for improving the quality of life' 